\title{
Oxidative Stress Induction by Lead in Leaves of Radish (Raphanus sativus) Seedlings
}

\author{
Nadjet BITEUR' ${ }^{1}$, Abdelkader AOUES², Omar KHAROUBI²*, Miloud SLIMANI ${ }^{2}$ \\ ${ }^{1}$ University of Science and Technology Mohamed BOUDIAF Oran (USTOMB), Department of \\ Molecular Genetic Applied, Laboratory of Biochemistry and Molecular Biology; Algeria \\ ${ }^{2}$ University Es-senia, Department of Biology, Laboratory of Biochemistry, Oran, Algeria; omarkharoubi@yahoo.fr ( ${ }^{*}$ corresponding author)
}

\begin{abstract}
Oxidative stress was induced by lead acetate $(\mathrm{Pb})$ in Raphanus sativus seedlings grown in a hydroponic system using sand as substrate. Thirty day old acclimated seeds were treated for 7 days with five Pb levels ( 0 as control, 100, 200, 500 and $1000 \mathrm{mg} \mathrm{l}^{-1}$ ). Parameters such as growth, oxidative damage markers (lipid peroxidation, protein oxidation and hydrogen peroxide contents) and enzymatic activities of catalase (CAT) and peroxidase (POD) were investigated. Lead concentration in plant tissues increased with increasing of $\mathrm{Pb}$ levels. Shoot fresh weight, chlorophyll and carotenoid concentration were significantly decreased at $100 \mathrm{mg} \mathrm{l}^{-1} \mathrm{~Pb}$. Lipid peroxidation, protein oxidation and $\mathrm{H}_{2} \mathrm{O}_{2}$ levels were increased at 500 and $1000 \mathrm{mg} \mathrm{l}^{-1} \mathrm{~Pb}$ compared to control treatment, in shoots. Peroxidase activity showed a straight correlation with $\mathrm{H}_{2} \mathrm{O}_{2}$ concentration, whereas CAT activity decreased only in shoots. These changes in enzymatic and non-enzymatic antioxidants showed that the Pb exposition had a significant disturbance on Raphanus sativus plantlets and affect the biochemical and physiological processes.
\end{abstract}

Keywords: hydrogen peroxide, lead, lipid peroxidation, oxidative stress, protein oxidation, Raphanus sativus

\section{Introduction}

Heavy metal pollution of air and agricultural soils is one of the most important ecological problems on world scale. According to the Environmental Protection Agency (EPA), $\mathrm{Pb}$ is the most common heavy metal contaminant in the environment (Watanabe, 1997). It is a nonessential element in metabolic processes and may be toxic or lethal to organisms even when absorbed in small amounts (Walker et al., 1996).

Lead contamination in the plant environment is known to cause highly toxic effects on processes such as depression on seed germination (Wierzbicka and Obidzinska, 1998), the disturbance in mitosis (Liu et al., 1994; Wierzbicka, 1994), induction of leaf chlorosis (Johnson and Proctor, 1977), toxicity of nucleoli (Liu et al., 1994), inhibition of root and shoot growth (Fargasova, 1994; Liu et al., 1994), reduction in photosynthesis (Poskuta et al., 1988; Poskuta and Waclawczyk-Lach, 1995) transpiration (Rolfe and Bazzaz, 1975), DNA synthesis (Gabara et al., 1992 ) and inhibition and activation of enzymatic activities (Van Assche and Cliisters, 1990). Lead not only affects plant growth and productivity but also enters into the food chain causing health hazards to man and animals (Seaward and Richardson, 1990).

lead toxicity is also known to induce oxidative stress through over production of reactive oxygen species (ROS) including superoxide radicals $\left(\mathrm{O}_{2}^{-}\right)$, hydroxyl radicals
$(\mathrm{OH})$ and hydrogen peroxide $\left(\mathrm{H}_{2} \mathrm{O}_{2}\right)$ (Reddy et al., 2005; Ruley et al., 2004; Verma and Dubey, 2003). These free radicals and hydrogen peroxides cause a variety of harmful effects in plant cells, such as inhibition of adenosine triphosphate (ATP) production, lipid peroxidation, and DNA damage (MacFarlanc, 2003). All these eventually lead to cell death. To combat oxidative damage, plants have antioxidant defense system comprising of enzymes of superoxide dismutase (SOD), catalase (CAT), peroxidase (POD), glutathione reductase (GR), and the non-enzymic constituents such as reduced glutathione (GSH) and ascorbate (As) that remove, neutralize, and scavenge ROS (Foyer et al., 1997; Lee et al., 1976; Navari-Lazzo and Quartacci, 2001). SOD dismutates $\mathrm{O}_{2}^{-}$to $\mathrm{H}_{2} \mathrm{O}_{2}$, and this is decomposed to $\mathrm{H}_{2} \mathrm{O}$ by POD and CAT, so that the accumulation of $\mathrm{O}_{2}^{-}$and $\mathrm{H}_{2} \mathrm{O}_{2}$ is effectively prevented (Liu et al., 2002).

Radish in considered to be a model cropand is widely used for studies related to heavy metal pollution (Khan and Frankland, 1983; Kostka-Rick and Manning, 1993). The advantage of using radish and other members of cabbage (Brassicaceae) family for heavy metal studies are well described by Mathe-Gaspar and Anron (2002) and it has economic and nutritional value, also is a rich source of two important medicinal compounds: peroxidases and isothiocyanates (Curtis, 2003).

Lead was recognized as causing oxidative stress in plants, so radish may have a strong resistance to $\mathrm{Pb}$, but 
94

little is known about the effects of $\mathrm{Pb}$ on the physiological processes of radish seedlings. The objective of the present investigation is to study the effects of different concentrations of $\mathrm{Pb}$ on leaf of radish including growth, physiological and biochemical processes such as the different pigments, soluble proteins, lipid peroxidation, protein oxidation and hydrogen peroxide contents; and the activities of some antioxidant enzymes (CAT and POD). The possible mechanisms of radish seedlings tolerance of $\mathrm{Pb}$ stress are briefly discussed in the present study.

\section{Materials and methods}

\section{Plant material}

Radish (Raphanus sativus, 'Early Menu') seeds were used for Petri-dish experiment. Seeds were surface sterilized with $0.1 \% \mathrm{HgCl}_{2}$ for the prevention of fungal and bacterial contamination (Young, 1926); and were grown hydroponically in aerated diluted (1: 4) Hoagland's nutrient solution containing various concentrations of $\mathrm{Pb}(0$, $100,200,500$ and $\left.1000 \mathrm{mg} \mathrm{l}^{-1}\right)$ were supplied exogenously as lead acetate $\left[\mathrm{Pb}\left(\mathrm{CH}_{3} \mathrm{COOH}\right)_{2}\right]$ for $24^{\circ} \mathrm{C}, 16 / 8 \mathrm{~h}$ light/ dark photoperiod and light intensity of $175 \mu \mathrm{M} \mathrm{m}^{-2} \mathrm{~s}^{-1}$. After 7 days of $\mathrm{Pb}$ exposure, the seedling fresh weight was determined and the shoots sample were kept at $-80^{\circ} \mathrm{C}$ for further analyses.

\section{Chlorophyll and carotenoid determination}

Fresh biomass (leaves) was homogenized in $80 \%$ icecold acetone in the dark and then centrifuged at $10000 \mathrm{~g}$ for $10 \mathrm{~min}$ at $4^{\circ} \mathrm{C}$ and the supernatant was used for the immediate determination of pigments. Absorbance of the solution was determined spectrophotometrically at 663 , 645 and $480 \mathrm{nM}$ the contents of chlorophyll a, b, and carotenoid, respectively; with the following equations help of Arnon's formulae (Arnon, 1949), for quantification of the total chlorophyll, chlorophyll a and chlorophyll b content in an $80 \%$ acetone extract:

Total chlorophyll $=20.2\left(\mathrm{~A}_{645}\right)+8.02\left(\mathrm{~A}_{663}\right)$

Chlorophyll $\mathrm{a}=12.7\left(\mathrm{~A}_{663}\right)-2.69\left(\mathrm{~A}_{645}\right)$

Chlorophyll $\mathrm{b}=22.9\left(\mathrm{~A}_{645}\right)-4.68\left(\mathrm{~A}_{663}\right)$

And Carotenoids $=\left(1000 \mathrm{~A}_{480}-3.27[\mathrm{chl} \mathrm{a}]-104[\mathrm{chl} \mathrm{b}]\right) / 227$

Chlorophyll and carotenoid concentrations were expressed as $\mathrm{mg} \mathrm{g}^{-1}$ fresh weight.

\section{Estimation of lipid peroxidation}

The level of peroxidation was measured in terms of malondialdehyde (MDA) (a product of lipid peroxidation) content determined by the thiobarbituric acid (TBA) reaction as described by Heath and Packer (1968). Frozen shoot was homogenized in $5 \mathrm{ml}$ of $0.1 \%$ trichloroacetic acid (TCA). The homogenate was centrifuged at $10000 \mathrm{~g}$ for $15 \mathrm{~min}$ and $4.0 \mathrm{ml}$ of $20 \%$ TCA containing $0.5 \% \mathrm{TBA}$ was added. The mixture was heated at $95^{\circ} \mathrm{C}$ for $30 \mathrm{~min}$ and then quickly cooled on ice bath. The contents were centrifuged at $10000 \mathrm{~g}$ for $15 \mathrm{~min}$ and the absorbance of the supernatant was measured at $532 \mathrm{nM}$ and the value for the non-specific absorption at $600 \mathrm{nM}$ was subtracted. The concentration of MDA was calculated using coefficient of absorbance of $155 \mathrm{mM}^{-1} \mathrm{~cm}^{-1}$. MDA content expressed as $\mathrm{nM} \mathrm{g}^{-1}$ fresh weight.

\section{Estimation of protein oxidation}

The reaction of carbonyls with 2, 4-dinitrophenylhydrazine (DNPH) was used to determine the amount of protein oxidation, as described by Levine et al. (1990). The shoots of radish seedlings was homogenized in a $25 \mathrm{mM}$ K-phosphate buffer ( $\mathrm{pH} 7.0$ ), containing $10 \mathrm{ml} \mathrm{l}^{-1}$ Triton $\mathrm{X}-100$ at a proportion of $1: 5(\mathrm{w}: \mathrm{v})$. The homogenate was centrifuged at $9000 \mathrm{~g}$ for $30 \mathrm{~min}$ at $4^{\circ} \mathrm{C}$. After the DNPHreaction, the carbonyl concentration was calculated by absorbance at $370 \mathrm{~nm}$, using the molar extinction coefficient $21 \mathrm{M}^{-1} \mathrm{~cm}^{-1}$ and expressed as $\mathrm{nM}$ carbonyl $\mathrm{mg}^{-1}$ protein.

\section{Determination of hydrogen peroxide}

The $\mathrm{H}_{2} \mathrm{O}_{2}$ concentration was determined according to Loreto and Velikova (2001). Approximately $0.1 \mathrm{~g}$ of shoots was homogenized at $4^{\circ} \mathrm{C}$ in $2 \mathrm{ml}$ of $0.1 \%$ trichloroacetic acid (TCA) (w: v). The homogenate was centrifuged at $12000 \mathrm{~g}$ for $15 \mathrm{~min}$ at $4^{\circ} \mathrm{C}$. Then, $0.5 \mathrm{ml}$ of the supernatant was added to $0.5 \mathrm{ml}$ of $10 \mathrm{mM} \mathrm{K}$-phosphate buffer $(\mathrm{pH}$ 7.0) and $1 \mathrm{ml}$ of $1 \mathrm{M} \mathrm{KI}$. The $\mathrm{H}_{2} \mathrm{O}_{2}$ concentration of the supernatant was evaluated by comparing its absorbance at $390 \mathrm{nM}$ with a standard calibration curve. Hydrogen peroxide concentration was expressed as $\mu \mathrm{M} \mathrm{g}^{-1}$ fresh weight.

\section{Catalase and peroxidase assay}

The frozen shoots material was homogenized in 50 $\mathrm{mM}$ Tris- $\mathrm{HCl}$ buffer ( $\mathrm{pH}$ 7.0). The supernatant solution was used to measure the activity of the enzymes, and the protein content was determined according to Bradford (1976).

Catalase (EC.1.11.1.6) activity was assayed by the method of Barber (1980). The reaction mixture consisted of enzyme extract, $5 \mathrm{mM} \mathrm{H}_{2} \mathrm{O}_{2}$ and $50 \mathrm{mM}$ Tris-buffer ( $\mathrm{pH} 7.0$ ). After $1 \mathrm{~min}$ incubation at $25^{\circ} \mathrm{C}$, the reaction was stopped by adding $1.0 \mathrm{ml}$ of $2.5 \mathrm{~N} \mathrm{H}_{2} \mathrm{SO}_{4}$. The residual $\mathrm{H}_{2} \mathrm{O}_{2}$ was titrated with $0.01 \mathrm{~N} \mathrm{KMnO}_{4}$ and measured spectrophotometrically at $240 \mathrm{~nm}$. Catalase activity was expressed as $\mathrm{ml} \mathrm{H}_{2} \mathrm{O}_{2}$ oxidized $\mathrm{g}^{-1}$ fresh weight $\mathrm{min}^{-1}$.

Peroxidase (EC.1.11.1.7) activity was assayed by the method of Kar and Mishra (1976). The reaction mixture contained $100 \mathrm{mM}$ Tris-buffer ( $\mathrm{pH}$ 7.0), $10 \mathrm{mM}$ pyrogallol and $5 \mathrm{mM} \mathrm{H}_{2} \mathrm{O}_{2}$. The reaction was started by adding $25 \mu \mathrm{l}$ enzyme solution and stopped after 5 min incubated at $25^{\circ} \mathrm{C}$ by adding $1.0 \mathrm{ml}^{2} .5 \mathrm{~N} \mathrm{H}_{2} \mathrm{SO}_{4}$. The amount of purpyrogallin formed was measured spectrophotometrically at $425 \mathrm{~nm}$. The enzyme activity was expressed as change in absorbance units $\mathrm{g}^{-1}$ fresh weight $\min ^{-1}$.

\section{Data analysis}

All data were analyzed in three replications and the obtained data were evaluated statistically using Student's ttest, and least significant difference (LSD) was calculated at $\mathrm{p}<0.05$. 
Results

\section{Growth and fresh weight}

The results after $7^{\text {th }}$ days of aqueous exposure of different lead levels in Radish seedlings showed considerable reduction in growth in respective doses of lead. The fresh weight of seedlings decreased on increasing the concentration of lead, the fresh weight was observed 92, 67, 36 and $20 \mathrm{mg} /$ seedling in respective concentration of lead (100, 200, 500 and $1000 \mathrm{mg} \mathrm{l}^{-1}$ ) in comparison to $125 \mathrm{mg}$ per seedling of control.

\section{Chlorophyll and carotenoid}

Increased lead exposure was noted in total chlorophyll as for example, they were $0.368,0.299,0.121$ and 0.031 $\mathrm{mg} \mathrm{g}^{-1}$ fresh weight of tissue in different concentration of lead $\left(100,200,500\right.$ and $\left.1000 \mathrm{mg} \mathrm{l}^{-1} \mathrm{~Pb}\right)$ in comparison to $0.406 \mathrm{mg} \mathrm{g}^{-1}$ fresh weight of control. Total carotenoids were $0.155,0.114,0.069$ and $0.032 \mathrm{mg} \mathrm{g}^{-1}$ fresh weight of tissue in 100, 200, 500 and $1000 \mathrm{mg} \mathrm{l}^{-1}$ of lead in comparison with $0.198 \mathrm{mg} \mathrm{g}^{-1}$ fresh weight of control (Tab. 1). Effect of $\mathrm{Pb}$ on Chlorophyll content $\mathrm{Chl} \mathrm{a}, \mathrm{Chl} \mathrm{b}$, total chlorophyll, and total carotene contents in radish seedlings were significantly $(\mathrm{p}<0.05)$ lower than control in all treatments (Tab. 1); although decrease in chlorophyll ' $\mathrm{b}$ ' was more marked than chlorophyll 'a'.

Tab. 1. Effect of lead on different pigments in radish (Raphanus sativus) seedlings

\begin{tabular}{|c|c|c|c|c|}
\hline \multirow[b]{2}{*}{ Treatments } & \multicolumn{3}{|c|}{$\begin{array}{c}\text { Chlorophyll } \\
\left(\mathrm{mg} \mathrm{g}^{-1} \text { Fresh tissue weight }\right)\end{array}$} & \multirow[t]{2}{*}{$\begin{array}{c}\text { Total carotenoid } \\
(\mathrm{mg} / \mathrm{g})\end{array}$} \\
\hline & $\mathrm{a}$ & $\mathrm{b}$ & Total & \\
\hline Control & $0.260 \pm 0,007$ & $0.119 \pm 0.009$ & $0.406 \pm 0.005$ & $0.198 \pm 0.004$ \\
\hline $\begin{array}{c}\mathrm{Pb} \\
100 \mathrm{mg} \mathrm{l}^{-1}\end{array}$ & $0.256 \pm 0.003$ & $0.110 \pm 0.005^{*}$ & $0.368 \pm 0.003$ & $0.155 \pm 0.003^{*}$ \\
\hline $\begin{array}{c}\mathrm{Pb} \\
200 \mathrm{mg} \mathrm{l}^{-1}\end{array}$ & $0.205 \pm 0.006^{*}$ & $0.083 \pm 0.007^{*}$ & $0.299 \pm 0.008^{*}$ & $0.114 \pm 0.008^{*}$ \\
\hline $\begin{array}{c}\mathrm{Pb} \\
500 \mathrm{mg} \mathrm{l}^{-1}\end{array}$ & $0.077 \pm 0.008^{*}$ & $0.041 \pm 0.004^{*}$ & $0.121 \pm 0.004^{*}$ & $0.069 \pm 0.006^{*}$ \\
\hline $\begin{array}{c}\mathrm{Pb} \\
1000 \mathrm{mg} \mathrm{l}^{-1}\end{array}$ & $0.016 \pm 0.002^{*}$ & $0.015 \pm 0.008^{*}$ & $0.031 \pm 0.002^{*}$ & $0.032 \pm 0.007^{*}$ \\
\hline
\end{tabular}

Tab. 2. Effect of lead on lipid peroxidation $\left(\mathrm{nM} \mathrm{g}^{-1}\right.$ fresh weight), protein oxidation (nM carbonyl $\mathrm{mg}^{-1}$ protein) and hydrogen peroxide ( $\mu \mathrm{M} \mathrm{g}^{-1}$ fresh weight) in radish (Raphanus sativus) seedlings

\begin{tabular}{|c|c|c|c|}
\hline Treatments & $\begin{array}{c}\text { Lipid } \\
\text { peroxidation }\end{array}$ & $\begin{array}{c}\text { Protein } \\
\text { oxidation }\end{array}$ & $\begin{array}{c}\text { Hydrogen } \\
\text { peroxide }\end{array}$ \\
\hline Control & $1.42 \pm 0.39$ & $2.22 \pm 0.47$ & $3.38 \pm 0.54$ \\
\hline $\mathrm{Pb} 100 \mathrm{mgl}^{-1}$ & $3.80 \pm 0.85$ & $2.58 \pm 0.63^{*}$ & $5.88 \pm 0.78^{*}$ \\
\hline $\mathrm{Pb} 200 \mathrm{mg} \mathrm{l}^{-1}$ & $4.65 \pm 0.77^{*}$ & $3.42 \pm 0.77^{*}$ & $7.19 \pm 1.88^{*}$ \\
\hline $\mathrm{Pb} 500 \mathrm{mg} \mathrm{l}^{-1}$ & $5.85 \pm 1.15^{*}$ & $4.62 \pm 0.82^{*}$ & $9.31 \pm 1.69^{*}$ \\
\hline $\mathrm{Pb} 1000 \mathrm{mg} \mathrm{l}^{-1}$ & $7.44 \pm 1.02^{*}$ & $5.10 \pm 1.19^{*}$ & $12.53 \pm 1.74$ \\
\hline
\end{tabular}

The averages of three replicates $\pm S E$ and $\left(^{*}\right)$ statistically significant at $\mathrm{p}<0.05$ level
Lipid peroxidation, protein oxidation and hydrogen peroxide

The lipid peroxidation were increased from 3.80, 4.65, 5.85 and $7.44 \mathrm{nM} \mathrm{MDA} \mathrm{mg}{ }^{-1}$ protein, the protein oxidation were increased from 2.58, 3.42, 4.62 and $5.10 \mathrm{nM}$ carbonyl $\mathrm{mg}^{-1}$ protein and the hydrogen peroxide were increased from 5.88, 7.19, 9.31 and $12.53 \mu \mathrm{M} \mathrm{g}^{-1}$ fresh weight of tissue, as compared to control where their values were 1.42, 2.22 and 3.38, respectively (Tab. 2).

\section{Soluble proteins, CAT and POD}

The soluble proteins were decreased from 46.5, 38, 27.5 and $16.44 \mathrm{\mu g} / \mathrm{g}$ in 100, 200, 500 and $1000 \mathrm{mg} \mathrm{l}^{-1}$ of lead respectively as compared to control when it was 51.27 $\mu \mathrm{g} / \mathrm{g}$ fresh weight of tissue. The catalase (CAT) was decreased from 28, 24, 22 and $20 \mathrm{ml} \mathrm{H}_{2} \mathrm{O}_{2}$ hydrolysed g ${ }^{-1}$ fresh weight of tissue and peroxidase (POD) activity was increased from $6.88,11.19,14.31$ and $15.32 \Delta$.O.D. $\mathrm{g}^{-1}$ fresh weight of tissue was noticed in all lead treatments as compared to control where their values were 37 and 2.38 respectively (Tab. 3).

Tab. 3. Effect of lead on soluble proteins $(\mu \mathrm{g} / \mathrm{g}$ fresh tissue weight), catalase ( $\mathrm{ml} \mathrm{H}_{2} \mathrm{O}_{2}$ hydrolysed $\mathrm{g}^{-1}$ fresh tissue weight) and peroxidase ( $\left(\right.$.O.D. $\mathrm{g}^{-1}$ fresh tissue weight) activities in radish (Raphanus sativus) seedlings

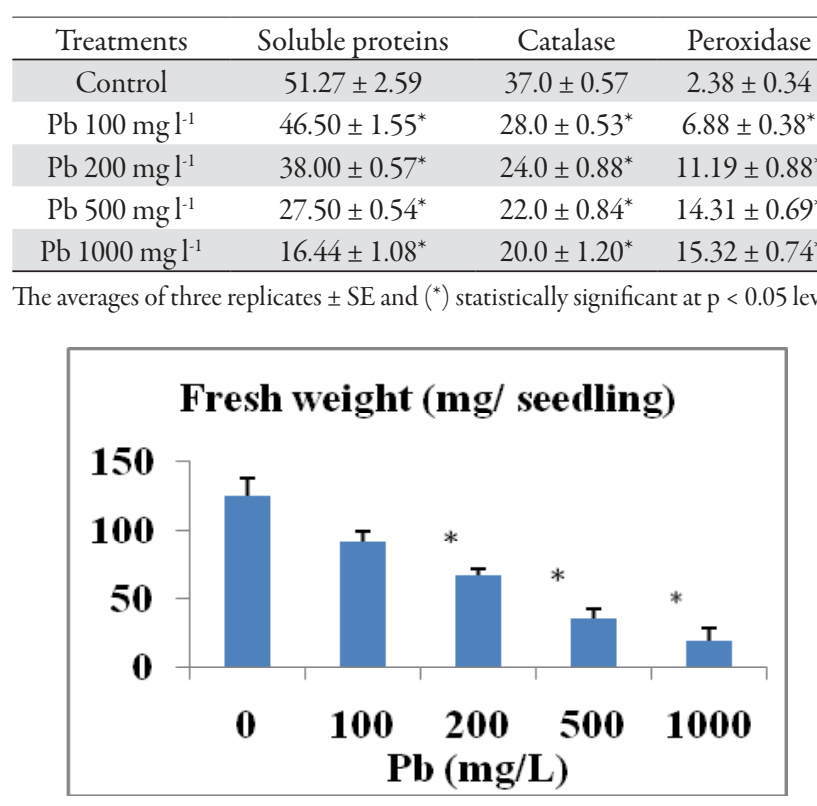

Fig. 1. Effect of lead on seedling growth in radish (Raphanus sativus). The averages of three replicates \pm SE and $\left({ }^{*}\right)$ statistically significant at $\mathrm{p}<0.05$ level.

\section{Discussion}

\section{$P b$ effects on growth, fresh and dry weight}

Lead is not generally considered an essential element for the growth of plants, but may stimulate growth of some plants in small amounts (Dou, 1988). The results from the present study show inhibitory effect of $\mathrm{Pb}$ on Raphanus sativus in seedling growth and shoot weight, exposed to 
96

$100,200,500$ and $1000 \mathrm{mg} \mathrm{l}^{-1} \mathrm{~Pb}$ during the whole experiment (Fig. 1). Apparently, radish is more tolerant to $\mathrm{Pb}$ on an equimolar basis compared to Brassica. juncea (Liu et al., 2000) and Allium cepa (Liu et al., 1994). Gopal and Rizvi (2008) were showed that excess $\mathrm{Pb}$ reduce the fresh and dry weight in leaves of radish at 30 day $(0.5 \mathrm{mM})$. The decrease of growth were shown in radish stressed with $\mathrm{Cd}$ (Anuradha and Rao, 2007) and in cucumber stressed with Al for 10 days (Perira et al., 2010). The results from Wierzbicka (1994) indicated that lead ions cause water deficit by disturbing water balance, which is one of the main factors which causes a poorer growth and development of plants. Seregin and Ivanov (1998) also observed 50\% inhibition of root growth in maize at $10^{-4} \mathrm{M}$ lead nitrate and browning of roots treated with $\mathrm{Pb}$ ions.

\section{Lead effect on chlorophyll and carotenoid}

As a visible symptom, the reduced chlorophyll and carotenoid concentrations can be used to monitor $\mathrm{Pb}$ induced damage in radish leaves (Tab. 1). In the present study, the reduction in chlorophyll concentration observed indicates oxidative damage induced by $\mathrm{Pb}$ exposure, possibly due to the inhibition of aminolevulinic acid dehydratase, an important enzyme in chlorophyll biosynthesis (Pereira et al., 2006). Similar to our observations, the chlorophyll level was reduce in wheat treated with $\mathrm{Ni}$ (Gajewska and Sktodowska, 2007), in maize treated with Cd (Jain et al., 2007), in radish treated with $\mathrm{Pb}$ (Gopal and Rizvi, 2008) and in cotyledons cucumber treated with Aluminum (Perira et al., 2010). Although the principal recognized role of carotenoids is to act as photoreceptive antenna pigment for photosynthesis, collecting wavelengths of light that are not absorbed by chlorophylls, their protective function against oxidative damage has also been recognized for several decades (Larson, 1988). Perhaps the most important function of carotenoid is the dissipation of excess energy of excited chlorophyll and the elimination of ROS (Lawlor, 2001).

\section{Lead effect on $M D A$}

Malondialdehyde is an oxidized product of membrane lipids, and accumulates when plants are exposed to oxidative stresses. Malondialdehyde concentration is commonly considered a general indicator of lipid peroxidation as well as stress level (Chaoui et al., 1997; Ding et al., 2004). An increase in MDA content in radish seedlings grown under $\mathrm{Pb}$ stress was observed (Tab. 2), indicating a high level of lipid peroxidation. it is possible that the increase in MDA concentration in the radish seedling may be due to a increase in polyunsaturated fatty acid concentration relative to saturated fatty acids, which has also been reported in radish under stressful conditions (Kramer et al., 1991). Our results show the conformity with the observations of Verma and Dubey (2003) in rice shoots and elevated the oxidative stress. Similar to our observations, lipid peroxidation is reported to be induced under Cd toxicity in rad- ish (Anuradha and Rao, 2007), under Ni toxicity in wheat (Gajewska and Sktodowska, 2007), and under Al toxicity in cucumber (Perira et al., 2010). This suggests that the toxic effect of heavy metals is probably exerted through free radical generation.

\section{Lead effect on carbonyl}

Despite being a non-redox metal, and thus not directly producing ROS (Benavides et al., 2005), Pb can interfere with antioxidant defense systems. Under stressful conditions the protective system can be over ridden by a rapid production of large amounts of ROS, leading to various structural modifications in proteins (Cargnelutti et al., 2006). These oxidative modifications are characterized by the formation of carbonyl derivatives on side chains of histidine, arginine, lysine, and proline residues (Shacter $e t$ al., 1994). Halliwell and Gutteridge (1999) suggested that the oxidation of proteins to form carbonyls occurs via the hydroxyl radical, since neither $\mathrm{H}_{2} \mathrm{O}_{2}$ nor superoxide is reactive enough to provoke oxidation. Carbonyl content is a sensitive indicator of oxidative damage to proteins (Levine et al., 1990), and levels of carbonylated proteins in plants demonstrate oxidative stress associated with heavy metals (Boscolo et al., 2003).

The data from the present study indicate an increase in protein oxidation levels in radish seedlings treated with $\mathrm{Pb}$ (Tab. 2).

The accumulation of carbonyls in the shoot of radish studied indicates that the quantity of radicals generated exceeded the capacity of the antioxidant defensive system.

Our data demonstrated that the seedling exposure to $1000 \mathrm{mg} \mathrm{l}^{-1}$ of $\mathrm{Pb}$ caused a remarkable increase in carbonyl formation, indicating that $\mathrm{Pb}$ promoted a high protein oxidation. This result is in agreement with that reported by Arvind and Prasad (2005) and Rellán-Álvarez et al. (2006) who noticed carbonyl accumulation in Ceratophyllum demersum and Zea mays plants exposed to $\mathrm{Cd}$. In another study, Cargnelutti et al. (2006) and Pereira et al. (2010) an increase in protein oxidation was showed in cucumber exposure to $\mathrm{Hg}$ and $\mathrm{Al}$, respectively.

\section{Effect of lead on hydrogen peroxide}

Hydrogen peroxide also appears to play an important role in signal transduction during plant abiotic stress. $\mathrm{H}_{2} \mathrm{O}_{2}$ produced from oxidative burst functions, such as a local trigger of programmed cell death of challenged cell, causes a rapid cross-linking of cell wall proteins (Levine $e t$ al., 1994). However, $\mathrm{H}_{2} \mathrm{O}$ is a signaling molecule, it must have regulated synthesis, specific responses and cellular targets, and there must be mechanisms for its metabolism or removal subsequent to signaling events (Neill et al., 2002). A possible component of a systemic signal is $\mathrm{H}_{2} \mathrm{O}_{2}$, whichst up an acclimatory response in unstressed regions of plant (Bhattacharjee, 2005). In the present study, the level of hydirogen peroxide was increased significantly, in the shoots of radish in all treatment with $\mathrm{Pb}$ compared 
with the control (Tab. 2). This result is similar to Tecklić et al. (2008) and Perira et al. (2010) who suggests an increased level of $\mathrm{H}_{2} \mathrm{O}_{2}$ in radish leaves treated with $\mathrm{Pb}$ and in cucumber treated with $\mathrm{Al}$.

Increased level of $\mathrm{H}_{2} \mathrm{O}_{2}$ is produced either due to action of SOD on superoxide radicals or by direct formation in biochemical pathways, photorespiration (Mishra et al., 2006).

\section{Pb effects on antioxidant enzyme}

To explore the mechanism how plants tolerated $\mathrm{Pb}$-induced oxidative stress, an examination of various antioxidant enzymes was performed. Activities of CAT and POD induced significantly at all $\mathrm{Pb}$ concentrations (Tab. 3).

This results show an increase of soluble protein content in shoots of radish seedlings in all treatment with lead. This increase is possible due to de novo synthesis of stress proteins provoked by metal exposure (Verma and Dubey, 2003). Cargnelutti et al. (2006) showed that Hgtreated cucumber presented increased in total soluble protein content.

CAT is one of the key enzymes in the removal of toxic peroxides. This is mostly universal oxide reductase that scavenges $\mathrm{H}_{2} \mathrm{O}_{2}$ via a two-electron transfer producing $\mathrm{O}_{2}$ and $\mathrm{H}_{2} \mathrm{O}$ ( $\mathrm{Lin}^{2}$ and Kao, 2000). The major function of CAT is to metabolize the peroxide liberated in the peroxisome following the conversion of glycollate during photorespiration (Qureshi et al., 2007). In the present study, in shoots of Raphanus sativus, the decrease in CAT activity under $\mathrm{Pb}$ concentration indicating removal of $\mathrm{H}_{2} \mathrm{O}_{2}$ and toxic peroxides and, in turn, the reduction in the free radical mediated lipid peroxidation under $\mathrm{Pb}$ toxicity. Lead decreased the activity of CAT in the shoot only in the Raphanus sativus at lower $\mathrm{Pb}$ concentrations.

However, with increasing Pb level, reduction in CAT activity was observed, which has been attributed to the activation of the enzyme protein (Feieraband and Engel, 1986) and the decrease in enzyme synthesis (Mittler, 2002). The decrease in CAT activity could indicate its inactivation by accumulation of $\mathrm{H}_{2} \mathrm{O}_{2}$ induced by lead in Cassia angustifolia (Qureshi et al., 2007).

POD is also an important enzyme, able to scavenge $\mathrm{H}_{2} \mathrm{O}_{2}$, which is a major substance degraded by SOD. The role of POD as a stress enzyme in plants has been widely accepted. POD activity has been suggested as a potential biomarker for metal toxicity in plant species (Agawal and Pandey, 2004). Induction of POD activity has been documented under many stress conditions such as $\mathrm{NaCl}$ stress (Agawal and Pandey, 2004), high temperature (El-Shintinawy et al., 2004) and toxic concentrations of $\mathrm{Cu}, \mathrm{Pb}, \mathrm{Zn}$, $\mathrm{Cd}$ and $\mathrm{Al}$ (Cakmak and Horst 1991; Guo et al., 2004; Radotic et al., 2000).

In the present investigation, radish exposed to 100 , 200, 500 and $1000 \mathrm{mg} \mathrm{l}^{-1} \mathrm{~Pb}$ showed a significant increase in POD activity in shoot compared with the control. POD activity was stimulated by the accumulation of per- oxide in the plants. Enhancement of POD activity in radish reflects its great capacity to acclimate to $\mathrm{Pb}$ stress by rapidly engaging an antioxidative defense system.

\section{Conclusions}

Thus, the finding that Raphanus sativus shows that it is good plant material for studying other aspects of abiotic stress resistance mechanisms. Based on the present work, it can be suggested that toxic concentrations of $\mathrm{Pb}$ cause oxidative stress, as evidenced by increased $\mathrm{H}_{2} \mathrm{O}_{2}$ formation, lipid peroxidation and oxidation of proteins in shoot of radish. In this study, a significant reduction in different parameters such as growth of shoot and roots, chlorophyll and carotenoid concentrations coupled with lipid peroxidation, protein oxidation and hydrogen peroxide indicated that high $\mathrm{Pb}$ levels in nutrient solution produced toxic effects. It was proposed that the reduced growth in $\mathrm{Pb}$ of radish exposed to toxic levels of $\mathrm{Pb}$ might be induced by an enhanced production of toxic oxygen species and subsequent lipid peroxidation. Moreover, it was possible to observe that $\mathrm{Pb}$-tolerant plants developed some defense mechanisms against oxidative stress. Further studies are required to investigate whether the oxidative stress caused by $\mathrm{Pb}$ toxic levels is an early symptom that can trigger shoot growth inhibition.

\section{References}

Agawal S, Pandey V (2004). Antioxidant enzyme responses to $\mathrm{NaCl}$ stress in Cassia angustifolia. Biol Plant 48:555-560.

Anuradha S, Rao SSR (2007). The effect of brassinosteroids on radish (Raphanus sativus L.) seedlings growing under cadmium stress. Plant Soil Environ 53:465-472.

Arnon DI (1949). Copper enzymes in isolated chloroplasts: Polyphenoloxidase in Beta vulgaris. Plant Physiol 24:1-15.

Arvind P, Prasad MNV (2005). Cadmium-zinc interactions in a hydroponic system using Ceratophyllum demersum L.: Adaptative ecophysiology, biochemistry and molecular toxicology. Braz J Plant Physiol 17:3-20.

Barber JM (1980). Catalase and peroxidase in primary leaves during development and senescence. Z Pflanzen Physiol 97:135-144.

Benavides MP, Gallego SM, Tomaro ML (2005). Cadmium toxicity in plants. Braz J Plant Physiol 17:21-34.

Bhattacharjee S (2005). Reactive oxygen species and oxidative burst: Roles in stress, senescence and signal transduction in plants. Curr Sci Ind 89:1113-1121.

Boscolo PRS, Menossi M, Jorge RA (2003). Aluminum-induced oxidative stress in maize. Phytochem 62:181-189.

Bradford MM (1976). A rapid and sensitive method for quantitation of microgram quantities of protein utilizing the principle of protein-dye binding. Anal Biochem 72:248254. 
98

Cakmak KB, Horst WJ (1991). Effect of aluminum on lipid peroxidation, superoxide dismutase, catalase and peroxidase activities in rot tips of soybean (Glycine max). Physiol Plant 83:463-468

Cargnelutti D, Tabaldi LA, Spanevello RM, Jucoski GO, Battisti V, Redin M, Linares CEB, Dressler VL, Flores EMM, Nicoloso FT, Morsch VM, Schetinger MRC (2006). Mercury toxicity induces oxidative stress in growing cucumber seedlings. Chemosphere 65:999-1006.

Chaoui A, Mazhoudi S, Ghorbal MH, Ferjani E (1997). Cadmium and zinc induction of lipid peroxidation and effects on antioxidant enzyme activities in bean (Phaseolus vulgaris L.). Plant Sci 127:139-147.

Curtis IS (2003). The noble radish: past, present and future. Trends Plant Sci 8:305-307.

Ding HD, Wan YH, Qi NM, Zhu WM, Yang XF, Shao YC (2004). Effects of $\mathrm{Cd}+2$ ? And $\mathrm{Zn}+2$ ? stress on antioxidant enzyme system of tomato seedlings. Acta Agr Shanghai 20:79-82 (in Chinese).

Dou ZX (1988). Lead pollution in soil and its effect on plants. Agro Environ Protect 3:38-39 (in Chinese).

EL-Shintinawy F, Ebrahim MKH, Sewelam N, Lshourbagy MN (2004). Activity of photosystem 2, lipid peroxidation, and the enzymatic antioxidant protective system in heat shocked barley seedlings. Photosynthetica 42:15-21.

Fargasova A (1994). Effect of $\mathrm{Pb}, \mathrm{Cd}, \mathrm{Hg}$, As and $\mathrm{Cr}$ on germination and root growth of Sinapis alba seeds. Bull Environ Contam Toxicol 52:452-456.

Feieraband J, Engel S (1986). Photoinactivation of catalase in vitro and in leaves. Arch Biochem Biophys 251:567-576.

Foyer CH, Lopez-Delgado H, Dat JF, Scott IM (1997). Hydrogen peroxide and glutathion-associated mechanisms of acclimatory stress tolerance and signaling. Physiol Plant 100:241-254.

Gabara B, Wojtyła-Kuchta B, Tarczynska M (1992). The effect of calcium on DNA synthesis in pea (Pisus sativus L.) roots after treatment with heavy metals. Folia Histochem Cytobiol 30:69-73.

Gajewska E, Sktodowska M (2007). Relations between tocopherol, chlorophyll and lipid peroxides content in shoots of Ni-treated wheat. J Plant Physiol 164(3):364-366

Gopal R, Rizvi AH (2008). Excess lead alters growth, metabolism and translocation of certain nutrients in radish. Chemosphere 70:1539-1544.

Guo TR, Zhang GP, Zhou MX (2004). Effects of aluminum and cadmium toxicity on growth and antioxidant enzyme activities of two barley genotypes with different $\mathrm{Al}$ resistance. Plant Soil 258:241-248.

Halliwell B, Gutteridge JMC (1999). Free radicals in biology and medicine. $3^{\text {rd }}$ ed. Clarendon Press, Oxford.

Heath RI, Packer L (1968). Photoperoxidation in isolated chloroplasts. I-Kinetics and stoichiometry of fatty acid peroxidation. Arch Biochem Biophysics 125:189-198.
Jain M, Pal M, Gupta P, Gadre R (2007). Effect of cadmium on chlorophyll biosynthesis and enzymes of nitrogen assimilation in greening maize leaf segments: role of 2-oxoglutarate. Ind J Experim Biol 45:385-389.

Johnson WR, Proctor JA (1977). Comparative study of metal levels in plants from two contrasting lead mine sites. Plant Soil 46:251-257.

Kar M, Mishra D (1976). Catalase, peroxidase, polyphenol oxidase activities during rice leaf senescence. Plant Physiol 57:315-319.

Khan DH, Frankland B (1983). Effect of cadmium and lead on radish plants with particular reference to movement of metals through soil profile and plants. Plant Soil 70:335345.

Kostka-Rick R, Manning WJ (1993). Radish (Raphanus sativus L.): a model for studying plant responses to air pollutants and other environmental stresses. Environ Poll 82:107-137.

Larson RA (1988). The antioxidants of higher plants. Phytochem 27: 969-978.

Lawlor DW (2001). Photosynthesis. $3^{\text {rd }}$ Ed. Bio Scientific Publishers, Oxford.

Lee KC, Cunningham BA, Chung KH, Paulsen GM, Liang GH (1976). Lead effects on several enzymes and nitrogenous compounds in soybean leaf. J Environ Qual 5:357-359.

Levine RL, Garland D, Oliver CN, Amici A, Climent I, Lenz AG, Ahn BW, Shaltiel S, Stadtman ER (1990). Determination of carbonyl content in oxidatively modified proteins. Methods Enzymol 233:346-357.

Levine A, Tenhaken R, Dixon R, Lamb C (1994). $\mathrm{H}_{2} \mathrm{O}_{2}$ from the oxidative burst orchestrates the plant hypersensitive disease resistance response. Cell 79:583-593.

Lin CC, Kao CH (2000). Effect of $\mathrm{NaCl}$ stress on $\mathrm{H}_{2} \mathrm{O}_{2}$ metabolism in rice leaves. Plant Growth Regul 30:151-155.

Liu DH, Jiang WS, Wang W, Zhao FM, Lu C (1994). Effects of lead on root growth cell division and nucleolus of Allium cepa. Environ Poll 86:1-4.

Liu DH, Jiang WS, Liu CJ, Xin CH, Hou WQ (2000). Uptake and accumulation of lead by roots, hypocotyls and shoots of Indian mustard (Brassica juncea L.). Bioresour Technol 71:273-277.

Liu DY, Wang YB, Zhang XX, Si Q (2002). Effect of sewage irrigation on wheat growth and its activated oxygen metabolism. J Appl Ecol 13:1319-1322 (in Chinese).

Loreto F, Velikova V (2001). Isoprene produced by leaves protects the photosynthetic apparatus against ozone damage, quenches ozone products, and reduces lipid peroxidation of cellular membranes. Plant Physiol 127:1781-1787.

MacFarlanc GR (2003). Chlorophyll a fluorescence as a potential biomarker of zinc stress in the grey mangrove Avicennia marina. Bull Environ Contam Toxicol 70:90-96.

Mathe-Gaspar G, Anton A (2002). Heavy metal uptake by two radish varieties. Acta Biol Szegediensis 46:113-114.

Mishra S, Srivastava S, Tripathi RD, Govindarajan R, Kuriakose 
SV, Prasad MNV (2006). Phytochelatin synthesis and response of antioxidants during cadmium stress in Bacopa monnieri L. Plant Physiol Biochem 44:25-37.

Mittler R (2002). Oxidative stress, antioxidants and stress tolerance. Trends Plant Sci 7:405-410.

Navari-Lazzo F, Quartacci MF (2001). Phytoremedition of metals: tolerance mechanisms against oxidative stress. Miner Biotechn 13:73-83.

Neill SJ, Desikan R, Hancock J (2002). Hydrogen peroxide signalling. Curr Op Plant Biol 5:388-395.

Pereira LB, Tabaldi LA, Gonçalves JF, Jucoski JO, Pauletto MM, Weis SN, Nicoloso FT, Borher D, Rocha JBT, Schetinger MRC (2006). Effect of aluminum on $\delta$-aminolevulinic acid dehydratase (ALA-D) and the development of cucumber (Cucumis sativus). Environ Exp Bot 57:106-115.

Pereira LB, Mazzanti CMA, Gonçalves JF, Cargnelutti D, Tabaldi LA, Becker AG, Calgaroto NS, Farias JG, Battisti V, Bohrer D, Nicoloso FT, Morsch VM, Schetinger MRC (2010). Aluminum-induced oxidative stress in cucumber. Plant Physiol Biochem 8(8):683-689.

Poskuta JW, Waclawczyk-Lach E (1995). In vivo responses of primary photochemistry of Photosystem II and $\mathrm{CO}_{2}$ exchange in light and in darkness of tall fescue genotypes to lead toxicity. Acta Physiol Plant 17:233-240.

Poskuta JW, Parys E, Romanowska E, Gajdzis-Gujdan H, Wroblewska B (1988). The effects of lead on photosynthesis, $14 \mathrm{C}$ distribution among photoassimilates and transpiration of maize seedlings. Acta Soc Bot Pol 57:149-155.

Qureshi MI, Abdin MZ, Qadir S, Iqbal M (2007). Leadinduced oxidative stress and metabolic alterations in Cassia angustifolia Vahl. Biol Plant 51:121-128.

Radotic K, Ducic T, Mutavdzic D (2000). Changes in peroxidase activity and isoenzymes in spruce needles after exposure to different concentrations of cadmium. Environ Exp Bot 44:105-113.

Reddy AM, Kumar SG, Jyonthsnakumari G, Thimmanaik S, Sudhakar C (2005). Lead induced changes in antioxidant metabolism of horsegram (Macrotyloma uniflorum (Lam.) Verdc.) and bengalgram (Cicer arietinum L.). Chemosphere 60:97-104.

Rellán-Álvarez R, Ortega-Villasante C, Álvarez-Fernández A, del Campo FF and Hernández LE (2006). Stress responses of Zea mays to cadmium and mercury. Plant Soil 279:4150 .
Rolfe GL, Bazzaz FA (1975). Effect of lead contamination on transpiration and photosynthesis of loblolly pine and autumn olive. For Sci 21:33-35.

Ruley AT, Sharma NC, Sahi SV (2004). Antioxidant defense in a lead accumulating plant, Sesbania drummondii. Plant Physiol Biochem 42(11):899-906.

Seaward MRD and Richardson DHS (1990). Atmospheric sources of metal pollution and effects on vegetation, p. 7592. In: Shaw AT (Ed.). Heavy Metal Tolerance in Plants: Evolutionary Aspects, CRC Press Inc., Boca Raton, FL.

Seregin IV, Ivanov VB (1998). The transport of cadmium and lead ions through root tissues. Rus J Plant Physiol 45:899905

Shacter E, Willians JA, Lim M, Levine RL (1994). Differential susceptibility of plasma proteins to oxidative modification: Examination by western blot immunoassay. Free Rad Biol Med 17:429-437.

Teklić T, Hancock JT, Engler M, Paradiković N, Cesar V, Lepeduš H, Štolfa I, Bešlo D (2008). Antioxidative responses in radish (raphanus sativus 1.) Plants stressed by copper and lead in nutrient solution and soil. Acta Biol Cracov Ser Bot 50:79-86.

Van Assche F, Cliisters H (1990). Effects of metals on enzyme activity in plants. Plant Cell Environ 13:195-206.

Verma S, Dubey RS (2003). Lead toxicity induces lipid peroxidation and alters the activities of antioxidant enzymes in growing rice plants. Plant Sci 164:645-655.

Walker CH, Hopkin SP, Sibly RM, Peakall DP (1996). Principles of Ecotoxicology. Taylor and Francis, Bristol, PA.

Watanabe MA (1997). Phytoremediation on the brink of commercialization. Environ Sci Technol 31:182A-186A.

Wierzbicka M (1994). Resumption of mitotic activity in Allium cepa root tips during treatment with lead salts. Environ Exp Bot 34:173-180.

Wierzbicka M, Obidzinska J (1998). The effect of lead on seed imbibition and germination in different plant species. Plant Sci 137:155-171.

Young AP (1926). Facultative parasitism and host range of fungi. Am J Bot 13:502-520. 